Potravinarstvo Slovak Journal of Food Sciences

vol. 15, 2021, p. 83-94

https://doi.org/10.5219/1530

Received: 18 December 2020. Accepted: 23 January 2021.

Available online: 28 February 2021 at www.potravinarstvo.com

(C) 2021 Potravinarstvo Slovak Journal of Food Sciences, License: CC BY 4.0

ISSN 1337-0960 (online)

\title{
THE MICROPERFORATED PACKAGING DESIGN AND EVALUATION OF SHELF LIFE OF FRESH-SLICED MUSHROOMS
}

\author{
Özlem Kizilirmak Esmer, Erinç Koçak, Aslı Şahiner, Can Türksever, \\ Pınar Akın, Aylin Acar, Nil Deniz Adman
}

\begin{abstract}
Fresh mushrooms have a very short shelf life, of $1-3$ days because of their high respiration rate and lack of cuticles that protect the plant from external factors. In the case of fresh-sliced mushrooms, they will be more susceptible to spoilage reactions due to the increase in respiration rate as a result of a broader surface area. Conventional packaging materials can not meet the requirements for modified atmosphere packaging of fresh-sliced mushrooms. One of the techniques to extend the fresh-cut produce shelf life is the passive modification of modified atmosphere packaging technology. For highly respiring fresh-cut produce such as fresh-sliced mushrooms, the permeability properties of the polymeric materials might not be enough to provide an equilibrium gas concentration in the passive modification of modified atmosphere technology. In this case, the microperforated packaging materials can be used for passive modification of fresh-cut produce. But the microperforation process needs a design for the application of the appropriate number and diameter of microholes to meet the requirements of passive modified atmosphere packaging. For this reason in this research, the design of the microperforation process to be used in passive modified atmosphere packaging was based on the diameter and the number of microholes, and the shelf life of fresh-sliced mushrooms was determined. The samples were stored at $15{ }^{\circ} \mathrm{C} / 80 \% \mathrm{RH}$, and $\mathrm{pH}$, color, weight loss, textural, sensorial, and microbial analysis were performed periodically during storage. It was determined that the empirical equation used in this research can be applied to microperforated packaging design for fresh-sliced mushrooms. The shelf life of the fresh-sliced mushrooms packaged with microperforated packaging material was 8 days, while it was less than 7 days $(4,5$, or 6 days) when packaged with non-microperforated packaging material. This result shows that the use of microperforated packaging material is effective in extending the shelf life of fresh-sliced mushrooms.
\end{abstract}

Keywords: modified atmosphere packaging; passive modification; fresh-sliced mushrooms; microperforation; shelf life

\section{INTRODUCTION}

Fresh mushrooms are known as very perishable commodities, with a short shelf life of $1-3$ days at ambient temperature. Due to their fine and porous epidermal cell structure, their respiration rate is higher compared to those of the other vegetables and fruits $\left(200-500 \mathrm{mg} \cdot \mathrm{kg}^{-1} \cdot \mathrm{h}^{-1}\right.$ at $20^{\circ} \mathrm{C}$ ) (Kader, 1986; Warwick and Tsureda, 1997; Singh et al., 2010). Their short shelf life can be attributed to the high respiratory rate of fresh mushrooms and also their lack of cuticles to protect them from physical or microbial changes or dehydration (Mau, Miklus and Beelman, 1993; Lee, 1999; Villaescusa and Gil Muñoz, 2003; Kamal et al., 2015). Slicing mainly accelerates the spoilage reactions since it leads to an increase in the respiration rate and creates a broader surface area susceptible to dehydration, browning, and microbial growth (Brennan and Gormley, 1998). This situation is also observable for fresh-sliced mushrooms. Several reactions such as browning, wilting, slaking, loss of water, textural deformations, loss of aroma, off-flavor occur more rapidly in the fresh-sliced mushrooms, and in this way, the shelf life of these products becomes shorter (Iqbal et al., 2009; Singh et al., 2010; Kamal et al., 2015).

Conventional polymeric films are unfavorable for the packaging of fresh-sliced mushrooms because their ratio of $\mathrm{CO}_{2}$ to $\mathrm{O}_{2}$ diffusion rates is high and this is not suitable for products requiring high $\mathrm{CO}_{2}$ and low $\mathrm{O}_{2}$ concentrations due to increased risk of anaerobiosis (Oliveira et al., 1998; Fonseca, Oliveira and Brecht, 2002). For this reason, microperforated polymeric materials may be an option to maintain the optimum gas concentrations in the package since diffusion rates of $\mathrm{O}_{2}$ and $\mathrm{CO}_{2}$ are very close to each other (Brody, 2005; Gonzalez-Buesa et al., 2009; Toivonen, Brandenburg and Luo, 2019; Cliff et al., 2010; Forney and Yaganza, 2011; Hussein, Caleb and Opara, 2015).

Microperforated films (perforation diameter $<200 \mu \mathrm{m}$ ) are commonly used in the modified atmosphere packaging (MAP) of fresh food products with high respiration rates; for example, minimally processed fruits and vegetables (González et al., 2008). The microperforations in the polymeric film allow a much higher exchange of gases than 
conventional polymeric films. The $\mathrm{O}_{2}$ concentrations in the headspace of the package used for the fresh-sliced mushrooms have been maintained below $5 \%$. This value must be higher than $1 \%$ to inhibit the growth of anaerobic and pathogenic microorganisms. The $\mathrm{CO}_{2}$ concentration in the headspace should be higher whereas higher concentrations than $12 \%$ might lead to physiological disorders and browning in mushrooms (Parentelli et al., 2007). Hence the use of microperforated packages for freshsliced mushrooms might be an alternative solution for the attainment of the desired gas combinations and the preservation of the quality characteristics of these products. So far, a limited number of studies concerning the extension of the shelf life of the fresh-cut produce mushrooms by using perforated polymeric films in packaging have been reported in the literature. Several scientists (Oliveira et al., 2012a) studied the optimum MAP conditions of the sliced mushrooms in packages perforated by a needle (each perforation has a diameter of $0.33 \mathrm{~mm}$ ) to achieve the best headspace gas composition, for maintaining quality and extending the shelf life of fresh-sliced mushrooms. In this study, they packed fresh-sliced button mushrooms in a tray covered with cellophane film and monitored the headspace gas composition and the quality characteristics of weight loss, $\mathrm{pH}$, firmness, and color at storage conditions of $10^{\circ} \mathrm{C}$ for 3 days. As a result, they found that the optimum packaging conditions as; $110 \mathrm{~g}$ of sliced mushrooms and 2 perforations in the film, leading to $3.6 \%$ of $\mathrm{O}_{2}$ and $11.5 \%$ of $\mathrm{CO}_{2}$ in the headspace gas composition, after 3 days at $10{ }^{\circ} \mathrm{C}$. In another research (Oliveira et al., 2012b), the authors examined the effect of temperature and number of perforations on the package on the quality of fresh-sliced mushrooms. Sliced mushrooms were packed in a tray, covered with cellophane film, and stored for 7 days at four levels of temperature $\left(0,5,10\right.$, and $\left.15^{\circ} \mathrm{C}\right)$ and three levels of perforations at each temperature ranging the number of perforations from 1 (58 perforations per $\mathrm{m}^{2}$ ) to 6 (349 perforations per $\mathrm{m}^{2}$ ). Headspace gas composition and quality parameters (weight loss, $\mathrm{pH}$, firmness, and color) were measured throughout the storage period. They found that at least one perforation was needed to avoid null $\mathrm{O}_{2}$ concentration that might lead to anaerobic respiration and the potential resulting in the growth of pathogens. They also showed that the needle diameter used $(0.33 \mathrm{~mm})$ was too big to use at lower temperatures, therefore a smaller needle diameter which might yield gas composition close to the optimal range is recommended. Fresh-sliced mushrooms had a shelf life of $1,2,4$, and 7.5 days at $15,10,5$, and $0{ }^{\circ} \mathrm{C}$, respectively, under optimum MAP conditions. In another study (Pogorzelska-Nowicka et al., 2020), the authors studied the effect of high oxygen atmosphere $\left(80 \% \mathrm{O}_{2}\right)$ in conjunction with Polysulfone films of different levels of microperforations $(6,12,23,25$ holes with a diameter of 90 $\mu \mathrm{m}, 91 \mu \mathrm{m}, 90 \mu \mathrm{m}$, and $143 \mu \mathrm{m}$ respectively) on antioxidant capacity, volatile compounds profile, sensory acceptance, and quality of fresh mushrooms stored at $20^{\circ} \mathrm{C}$ for 5 days. Some authors (Rivera et al., 2010) studied the design of modified atmosphere packaging suitable for Tuber melanosporum and Tuber aestivum truffles that extend their shelf life and their availability as a fresh product. They found that the microperforated film with 2 holes $(90 \times 50 \mu \mathrm{m})$ was the best to be used in modified atmosphere packaging of fresh truffles. The quality and microbiological characteristics of fresh truffles, packaged in this film revealed that the microbial counts of Pseudomonads and Enterobacteriaceae were decreased, the weight loss was reduced, the typical hard texture was maintained, and the development of mycelium growth was delayed, enabling good scores for aroma and flavor, and therefore prolonging the shelf life of T. melanosporum and T. aestivum truffles to 28 and $21 \mathrm{~d}$, respectively.

To maintain the quality and extend the shelf life of freshsliced mushrooms packaged with the microperforated packaging materials during the storage period, the design of the perforation process is necessary. This design must be performed carefully by taking the possible effects of several parameters in the perforation into consideration. The size and the number of microperforations in the polymeric packaging material are the key parameters for the microperforation process. In a polymeric film, the gas transmission rate (TR) is directly proportional to the area of the perforation. The $\mathrm{O}_{2}$ or $\mathrm{CO}_{2}$ transmission rates of a microhole with a mean diameter can be calculated by using the initial $\mathrm{O}_{2}$ and $\mathrm{CO}_{2}$ concentrations in the headspace and the equilibrium gas composition, the number of perforations required in a packaging film can be calculated with the $\mathrm{O}_{2}$ or $\mathrm{CO}_{2}$ transmission rates (González et al., 2008).

\section{Scientific Hypothesis}

The hypothesis of this study was to determine whether the shelf life of freshly sliced mushrooms could be extended by using microperforated packaging materials compared to non-perforated packaging materials in passive modified atmosphere packaging. The microperforation process should be designed according to the requirements of gas compositions of the headspace of passive modified atmosphere packaging and the respiration rate of the product. Therefore the objectives of this research are (i) to optimize the number of microperforations performed by laser perforation technique in packaging material of freshsliced mushrooms at a storage temperature of $15{ }^{\circ} \mathrm{C}$ to which the product can be exposed during storage in the market, (ii) to determine the shelf life of the fresh-sliced mushrooms packaged with this optimized microperforated packaging material by analyzing the headspace gas concentrations, $\mathrm{pH}$, weight loss, color, hardness, microbiological and sensorial properties of the mushrooms.

\section{MATERIAL AND METHODOLOGY}

\section{Samples}

White button mushrooms (Agaricus bisporus) were supplied by the Gülen Mushroom Farm (Antalya, Türkiye) and transported to Ege University (Izmir, Türkiye) at $4 \pm 2{ }^{\circ} \mathrm{C}$ and $80 \% \pm 1 \mathrm{RH}$. Transparent, heat sealable, and antifog biaxially oriented polypropylene (BOPP) with a film thickness of $30 \mu \mathrm{m}$ was used as the packaging material provided by the Bak Ambalaj Inc. (Izmir, Türkiye).

\section{Chemicals}

Plate Count Agar (Merck, United States), Pseudomonas CFC Agar (Merck, United States), Pseudomonas CFC Selective Supplement (Merck, United States), and Peptone from Casein (Merck, United States) were used in microbiological analysis. 


\section{Instruments}

The changes in the oxygen and carbon dioxide concentrations during storage in the headspace of the packaging materials were measured by the headspace analyzer (PBI Dansensor Checkmate, Ringsted, Denmark). The microperforation process of the packaging films was performed using UV Laser equipment (Laseral, Izmir, Turkey) having F100 optical and $355 \mathrm{~nm}$ lenses. The diameters of the holes were determined via a stereomicroscope (Leica CLS $150 \mathrm{XE}$, Germany) and their image was monitored by scanning electron microscopy (SEM Thermo Scientific Apreo II). The $\mathrm{pH}$ measurements were made by the device HANNA HI83141 (Rhode Island, USA). The color changes and Hunter color values $\left(\mathrm{L}^{*}, \mathrm{a}^{*}\right.$ and $b^{*}$ ) of the sliced mushrooms were determined using Hunter colorimeter (Colorflex, CFLX 45-2 model Colorimeter, Hunter Lab, Reston, VA). The hardness of the samples was analyzed using the texture analyzer (Stable Micro System, Txt Plus, UK) equipped with a cylindrical probe (P/R 36).

\section{Laboratory Methods}

Oxygen and water vapor permeability tests were conducted by the standardized methods (ASTM D3985, 2017) at $25{ }^{\circ} \mathrm{C}$ and $0 \% \mathrm{RH}$ and (ASTM F1249, 2020) at $37.8{ }^{\circ} \mathrm{C}, 90 \% \mathrm{RH}$ respectively. The TAMB count was performed as described by the method described in the ISO 4833-1 (2013). The principle of the count of Pseudomonas spp. is based on the method described by ISO 13720 (2010).

\section{Sample preparation}

The mushrooms were dried and sliced at a thickness of $0.5 \mathrm{~cm}$ after being separated manually and washed to eliminate the specks of dirt. Then, they were first placed into the trays made of polystyrene foam (each tray contains $125 \mathrm{~g}$ of mushrooms). These trays were placed in pouches of 21 x $29.7 \mathrm{~cm}$ made of microperforated and nonperforated BOPP. The pouches were heat-sealed afterward. The samples were stored for 10 days in a climate cabinet (Nüve- TK 120, Turkey) at $15 \pm 1{ }^{\circ} \mathrm{C}$ and $80 \% \pm 1 \mathrm{RH}$. The shelf life analysis was conducted periodically on days 0,2 , $4,7,8,9$, and 10 of the storage.

\section{Determination of the respiration rate}

The respiration rate of the mushrooms was determined by monitoring the change in the gas concentration inside the leak-proof packaging material throughout the entire storage process of the product. For this purpose, sliced mushroom samples (each of $200 \mathrm{~g}$ ) were stored in the glass jars of $5 \mathrm{~L}$ at $15{ }^{\circ} \mathrm{C}$ for 24 hours. The initial and final gas concentrations were measured by the headspace analyzer (PBI Dansensor Checkmate, Ringsted, Denmark). The respiration rate in terms of $\mathrm{O}_{2}$ and $\mathrm{CO}_{2}$ were calculated using equation (1) and equation (2) respectively.

$$
\begin{aligned}
& R_{m 1}=\left(A_{i}-A_{f}\right) \times \frac{V}{100} \\
& R_{m 2}=C_{f} \times \frac{V}{100}
\end{aligned}
$$

Where:

$\mathrm{R}_{\mathrm{m} 1}, \mathrm{R}_{\mathrm{m} 2}$ : Respiration rate; $\mathrm{A}_{\mathrm{i}}$ : Initial $\mathrm{O}_{2}(\%)$ concentration $(21 \%)$, Af: Final $\mathrm{O}_{2}(\%)$ concentration; $\mathrm{C}_{\mathrm{f}}$ : Final $\mathrm{CO}_{2}$ concentration $(\%), \mathrm{V}=$ Volume of the jar, $(\mathrm{mL})$.
Microperforated packaging design

Determination of the diameter of the micro holes

The standardization of the micro perforation was carried out by the adjustment of the point time (PT) which determines the focusing time of the beams and the optimal diameter and number of the holes. Several PT's were tried in nine replicates and the optimum PT has been determined to obtain standard diameter and circular holes. The diameters of the holes were determined via a stereomicroscope (Leica CLS $150 \mathrm{XE}$ ) and their image was monitored by scanning electron microscopy (SEM Thermo Scientific Apreo II, USA). Minimum three replicates were performed for this process.

\section{Determination of the number of holes concerning the respiration rate}

The number of holes micro perforated on the packaging film was calculated by considering the following parameters: The $\mathrm{CO}_{2}$ transmission rate of the microhole, the headspace volume, the $\mathrm{CO}_{2}$ volume in excess in the headspace. The $\mathrm{CO}_{2}$ transmission rate was calculated by using the mean diameter of the measurements and equation (3) (González et al., 2008).

$$
T R=a_{1} A_{h}^{a_{2}}
$$

Where;

$\mathrm{TR}=\mathrm{CO}_{2}$ or $\mathrm{O}_{2}$ transmission rate $\left(\mathrm{mL} \mathrm{day}^{-1}\right) ; \mathrm{a}_{1}, \mathrm{a}_{2}$ are the constants for $\mathrm{O}_{2}$ or $\mathrm{CO}_{2} ; \mathrm{A}_{h}=$ area of each microhole $\left(\mu \mathrm{m}^{2}\right)$.

\section{Determination of the shelf life of the fresh-sliced mushrooms}

Headspace, pH, weight loss, color, hardness, microbiological, and sensory analyses were performed to determine the shelf life of the mushrooms. Each analysis was conducted in triplicate. The storage process of microperforated packaged samples was performed with two replicates.

\section{Headspace analysis}

The PBI Dansensor Checkmate (Ringsted, Denmark) digital analyzer was used to determine the $\mathrm{O}_{2}$ and $\mathrm{CO}_{2}$ concentrations in the headspace.

\section{pH}

$10 \mathrm{~g}$ of sample was homogenized with distilled water of $50 \mathrm{~mL}$ and then the measurement was performed with a $\mathrm{pH}$ meter.

\section{Weight loss}

It was determined gravimetrically and expressed in terms of percentage. The weight loss was calculated using the following equation:

$$
\Delta \mathrm{M}=\frac{\mathrm{M}_{i}-\mathrm{M}_{t}}{\mathrm{M}_{t}} \times 100
$$

Where:

$\Delta \mathrm{M}, \mathrm{M}_{\mathrm{i}}$, and $\mathrm{M}_{\mathrm{t}}$ denote the percentage change in the weight loss, initial weight, and weight at the instance of measurement respectively. 


\section{Color}

The color analysis was carried out by assessing $\mathrm{L}^{*}, \mathrm{a}^{*}$, and $b^{*}$ values. The instrument was calibrated with black and white standard plates before the analysis. The reported data are the mean of eight measurements made for each sample. Total color difference $(\Delta \mathrm{E})$ and browning index $(\mathrm{BI})$ were calculated by using the equations below.

$$
\begin{aligned}
& \Delta \mathrm{E}=\sqrt{\Delta \mathrm{L}^{2}+\Delta \mathrm{a}^{2}+\Delta \mathrm{b}^{2}} \\
& \mathrm{BI}=\frac{100(\mathrm{x}-0.31)}{0.172} \\
& \mathrm{x}=\frac{\mathrm{a}+1.75 \mathrm{~L}}{5.645 \mathrm{~L}+\mathrm{a}-3.012 \mathrm{~b}}
\end{aligned}
$$

\section{Hardness}

Five slices of each sample lot were analyzed in terms of hardness. The test velocity and the compression rate were adjusted as $1.5 \mathrm{~mm} . \mathrm{s}^{-1}$ and $75 \%$ respectively. The hardness of the sample was expressed in terms of the maximum force (g). The analysis was conducted in triplicate.

\section{Microbiological analysis}

The microbiological growth during the storage of the samples was observed to determine the shelf life of the mushrooms. To detect the initial amount of microorganisms in mushrooms, total aerobic mesophilic bacteria, Pseudomonas spp., Escherichia coli, Staphylococcus aureus, Salmonella spp., Listeria monocytogenes, and E.coli $\mathrm{O} 157$ analysis were performed on day 0. During the shelf life, total aerobic mesophilic bacteria and Pseudomonas spp. counts, which are the parameters affecting the shelf life of mushrooms, were determined. The mushroom samples were prepared in ten-fold dilutions and homogenized by using appropriate diluents.

\section{Total aerobic mesophilic bacteria count (TAMB)}

Briefly, $10 \mathrm{~g}$ of mushroom samples were added into the stomacher bags containing $90 \mathrm{~mL} 0.1 \%$ peptone solution. The samples were serially diluted in $0.1 \%$ peptone solution to the appropriate concentration after homogenization. The analysis was performed by the pour plate method using Plate Count Agar (PCA, Merck). The colonies were counted and the $\mathrm{CFU} \mathrm{g}{ }^{-1}$ was calculated after incubation of the plates at $30 \pm 1{ }^{\circ} \mathrm{C}$ for 72 hours.

\section{Pseudomonas spp. count}

10 grams of the samples were weighed into Stomacher bags under aseptic conditions, and decimal serial dilutions were prepared until $10^{-7}$. $0.1 \mathrm{~mL}$ of each decimal dilution were spread over the surface of Pseudomonas CFC Agar (Merck) plates and incubated at $25^{\circ} \mathrm{C} \pm 1{ }^{\circ} \mathrm{C}$ for $48 \mathrm{~h} \pm 2 \mathrm{~h}$. After incubation, Petri dishes containing 30-300 colonies were counted.

\section{Sensory evaluation}

The sensory characteristics of the sliced mushrooms were assessed in terms of texture, odor, appearance, and overall acceptability by five trained panelists. For the evaluation, a scoring test including the hedonic scale ranging between 1 and 5 was used. The samples having a score higher than or equal to 3 were evaluated as acceptable in the sensory tests.

\section{Statistical Analysis}

The experimental data were analyzed using the SPSS software (IBM Corp., 2013). Homogeneity of the variance tests was performed by the Levene statistics. The statistically significant differences among the sample groups were determined using one-way ANOVA. The tests concerning the differences between the sample groups with non-homogenous distribution were carried out using MannWhitney U tests. The standard deviations of the means were computed in a spreadsheet (Microsoft Excel, Office 2016, Microsoft Corporation).

\section{RESULTS AND DISCUSSION}

\section{Determination of the respiration rate}

The respiration rates of the fresh-sliced mushrooms after 24 hours of storage were measured $1925.27 \pm 159.6$ and $1782.38 \pm 105.291 \mathrm{~mL}\left(\mathrm{~kg}^{-1} \cdot 24 \mathrm{~h}^{-1}\right)$ for $\mathrm{O}_{2}$ and $\mathrm{CO}_{2}$ respectively.

\section{Determination of the diameter and number of the microholes}

For standardization in terms of the uniformity of the microholes, other parameters except for the point time (PT) were kept constant. The optimized PT was determined as 0.9 to obtain uniform microholes each having a diameter of $25.6 \pm 3.96 \mu \mathrm{m}$. This value was used in the calculation of the number of microholes. The SEM image of such a microhole with a diameter of $25.22 \mu \mathrm{m}$ was presented in Figure 1.

The TR of the $\mathrm{CO}_{2}$ and $\mathrm{O}_{2}$ were calculated using Equation (3) for a single hole with a mean diameter of $25.6 \mu \mathrm{m}$ as 28.97 and $32.29{\mathrm{~mL} . \text { day }^{-1}}$ respectively. The headspace volume was determined as $310 \mathrm{~mL}$ which was calculated by subtracting the volume occupied by $125 \mathrm{~g}$ mushrooms $(130 \mathrm{~mL})$ from the total volume of the polystyrene foam tray $(440 \mathrm{~mL})$. In the literature, it was reported that the value for the $\mathrm{CO}_{2}$ transmission rate should not exceed $12 \%$ (Parentelli et al., 2007). This rate was corresponding to $37.2 \mathrm{~mL}$ in our experiments. The $\mathrm{TR}$ of $\mathrm{CO}_{2}$ for $125 \mathrm{~g}$ of mushrooms was calculated $222.8 \mathrm{~mL}$ by using the mean value for $\mathrm{CO}_{2}\left(1782.38 \mathrm{~mL} \cdot \mathrm{kg}^{-1}\right.$.day $\left.{ }^{-1}\right)$. The volume of $\mathrm{CO}_{2}$ in excess in the package was computed $185.6 \mathrm{~mL}$ by subtracting the maximum allowable $\mathrm{CO}_{2}$ rate in the package $(37.2 \mathrm{~mL})$ from the $\mathrm{TR}$ of $\mathrm{CO}_{2}$. This value $(185.6 \mathrm{~mL})$ refers to the volume of $\mathrm{CO}_{2}$ that must be discharged from the package per day. The number of microholes was calculated as 6.41 (approx. 6) by dividing $185.6 \mathrm{~mL}$ by the $\mathrm{CO}_{2}$ permeability of a single microhole $\left(28.97 \mathrm{~mL}^{- \text {day }^{-1}}\right)$.

The design of UV laser perforation was performed with 6 microholes and shown in Figure 2.

\section{Determination of the permeability of the BOPP films}

To reveal the effectiveness of the microperforation, the permeability tests were conducted for both non-perforated and microperforated samples. The oxygen transmission rate (OTR) and water vapor transmission rate (WVTR) of the BOPP films were measured for microperforated samples as $3184.9 \pm 89.9$ cc.m ${ }^{-2}$.day ${ }^{-1}$ and $31.0 \pm 1.3$ g.m ${ }^{-2}$. day ${ }^{-1}$ and non-perforated samples as $1300.0 \pm 25.15{\mathrm{cc} . \mathrm{m}^{-2} \text {. day }}^{-1}$ and $6 \pm 0.24$ g. $\mathrm{m}^{-2}$. day ${ }^{-1}$ respectively. 


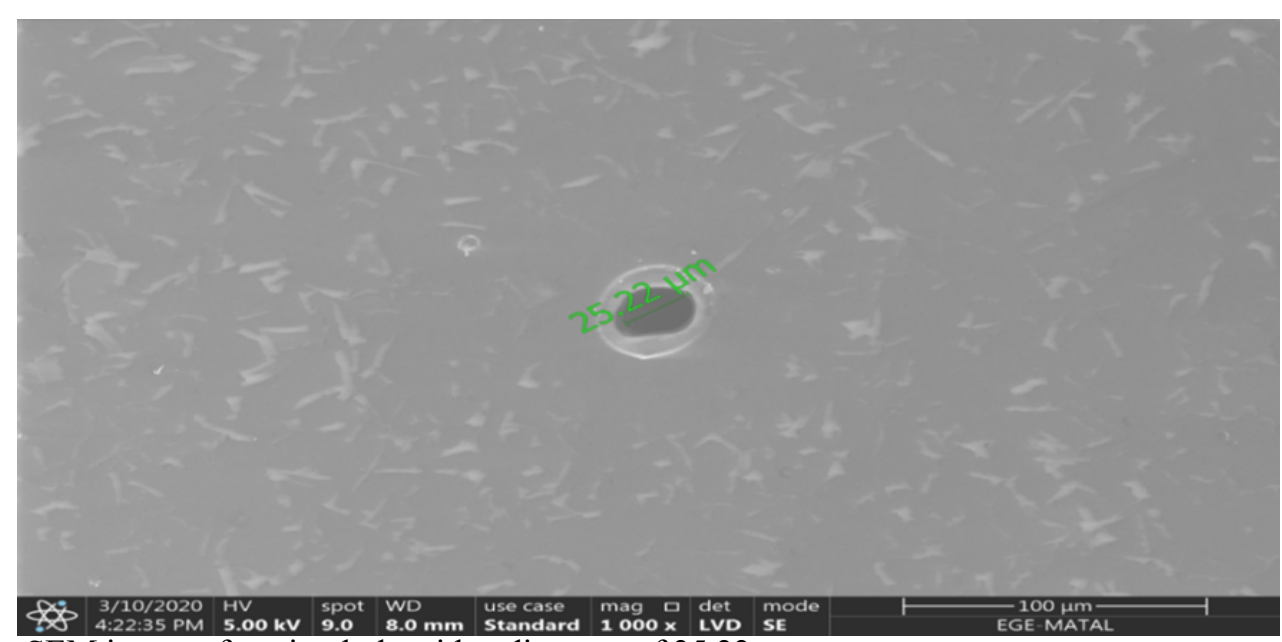

Figure 1 The SEM image of a microhole with a diameter of $25.22 \mu \mathrm{m}$.

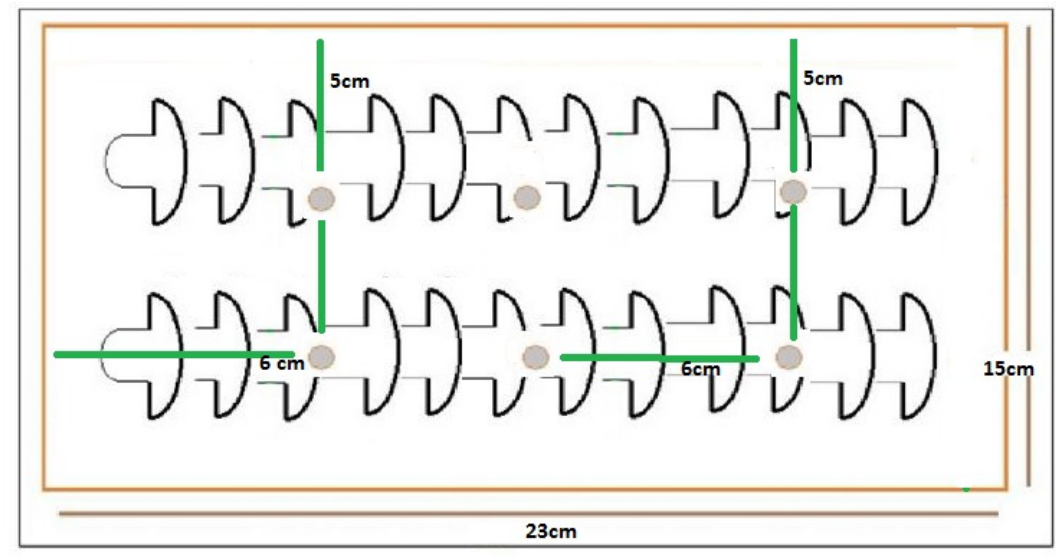

Figure 2 The schematic design of the microperforated BOPP films showing the microperforated holes on the package.

The microperforation seemed to be successful since the OTR and WVTR values of the BOPP films increased drastically in this way. The effect of the enhancement in the permeability on the shelf life of the mushrooms was described in detail under the title "Determination of the shelf life of the fresh-cut mushrooms" section.

\section{Validation of the empirical TR formula using permeability test results}

To validate the empirical formula described in the research (González et al., 2008), the $\mathrm{TR}$ of $\mathrm{O}_{2}$ for 6 microholes was calculated as $193.7 \mathrm{~mL}$ (32.29 mL.day ${ }^{-1} \mathrm{x}$ 6). Using Eq. (3) with the dimensions of BOPP films $(0.21 \times 0.297 \mathrm{~m})$ and the $\mathrm{O}_{2}$ transmission rate $\left(3184.9 \mathrm{cc} . \mathrm{m}^{-2}\right.$.day $\left.{ }^{-1}\right)$ determined experimentally, the volume of $\mathrm{O}_{2}$ was calculated $198.6 \mathrm{~mL}^{- \text {day }^{-1}}$ for 6 microholes which were indicating that the theoretical and experimental TR of $\mathrm{O}_{2}$ were close to each other and the empirical formula was applicable in this case.

\section{Determination of the shelf life of the fresh-sliced mushrooms}

To determine the shelf life of the mushrooms, the samples were stored at $15{ }^{\circ} \mathrm{C}, \quad 80 \% \mathrm{RH}$ for 10 days in microperforated and non-perforated BOPP packages. Before starting with the analysis on the day of the experiment, the photos of each sample were taken and presented in Figure 3.

\section{The quantitative changes in the headspace gas} composition during storage

The deterioration of the mushrooms might be caused by the impact of several anaerobic conditions, which also depend on the $\mathrm{O}_{2}$ level in the headspace and accelerate the spoilage when the $\mathrm{O}_{2}$ level becomes less than $1 \%$, which may result in the tissue softening and undesired odors (Parentelli et al., 2007). Almenar et al. (2007) and De Reuck, Sivakumar and Korsten (2009) revealed that extremely low oxygen levels in the headspace might trigger anaerobic reactions which result in off-odors and offflavors. Thus, the $\mathrm{O}_{2}$ level measured in the headspace might be a good indicator for microbial spoilage. On the other hand, $\mathrm{CO}_{2}$ was claimed to have an important role in the retention of textural characteristics, when it is present at high concentrations in the headspace (Gonzalez-Fandos et al., 2001; Simón, Gonzáles-Fandos and Tobar, 2005). The quantitative changes in the headspace gas composition were presented in Figure 4.

As seen in Figure 4, the $\mathrm{O}_{2}$ level in the headspace declined to $0.45 \%$ after 4 days of storage in the non-perforated samples, whereas it fell below $1 \%(0.4 \%)$ after 9 days of storage in the microperforated samples. Consequently, one might state that the microbiological spoilage might have started after 4 days in the non-perforated samples, and after 9 days of storage in the microperforated group. 

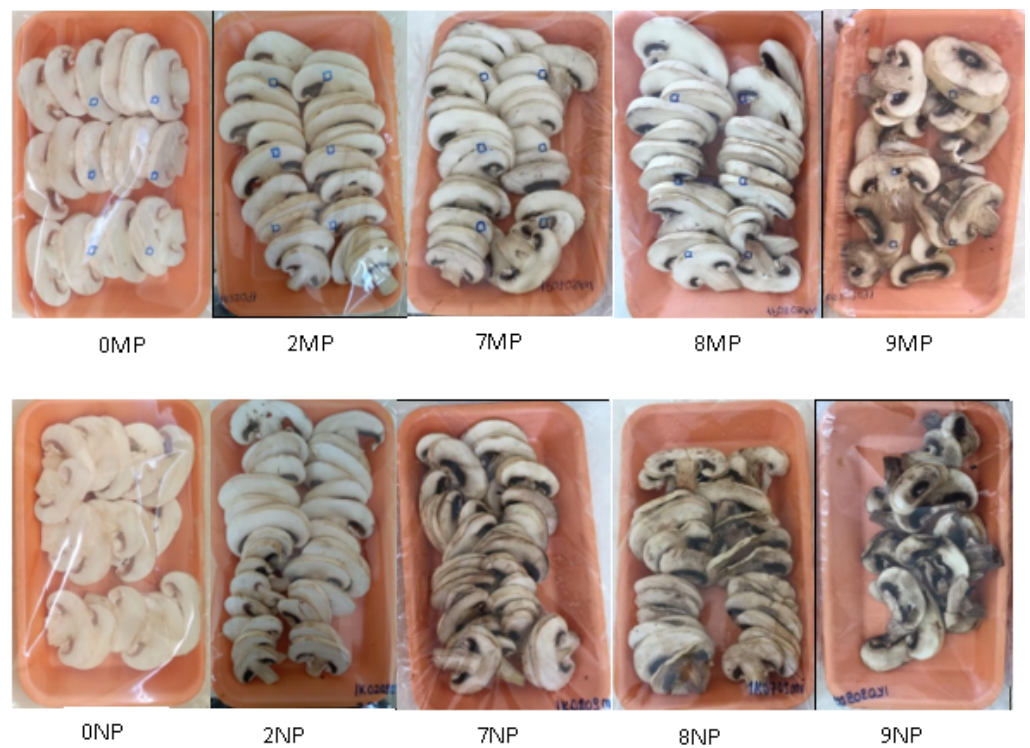

Figure 3 Microperforated (MP) and non-perforated (NMP) packaged samples during storage period of $0^{\text {th }}, 2^{\text {nd }}, 7^{\text {th }}, 8^{\text {th }}$, $9^{\text {th }}$ days.

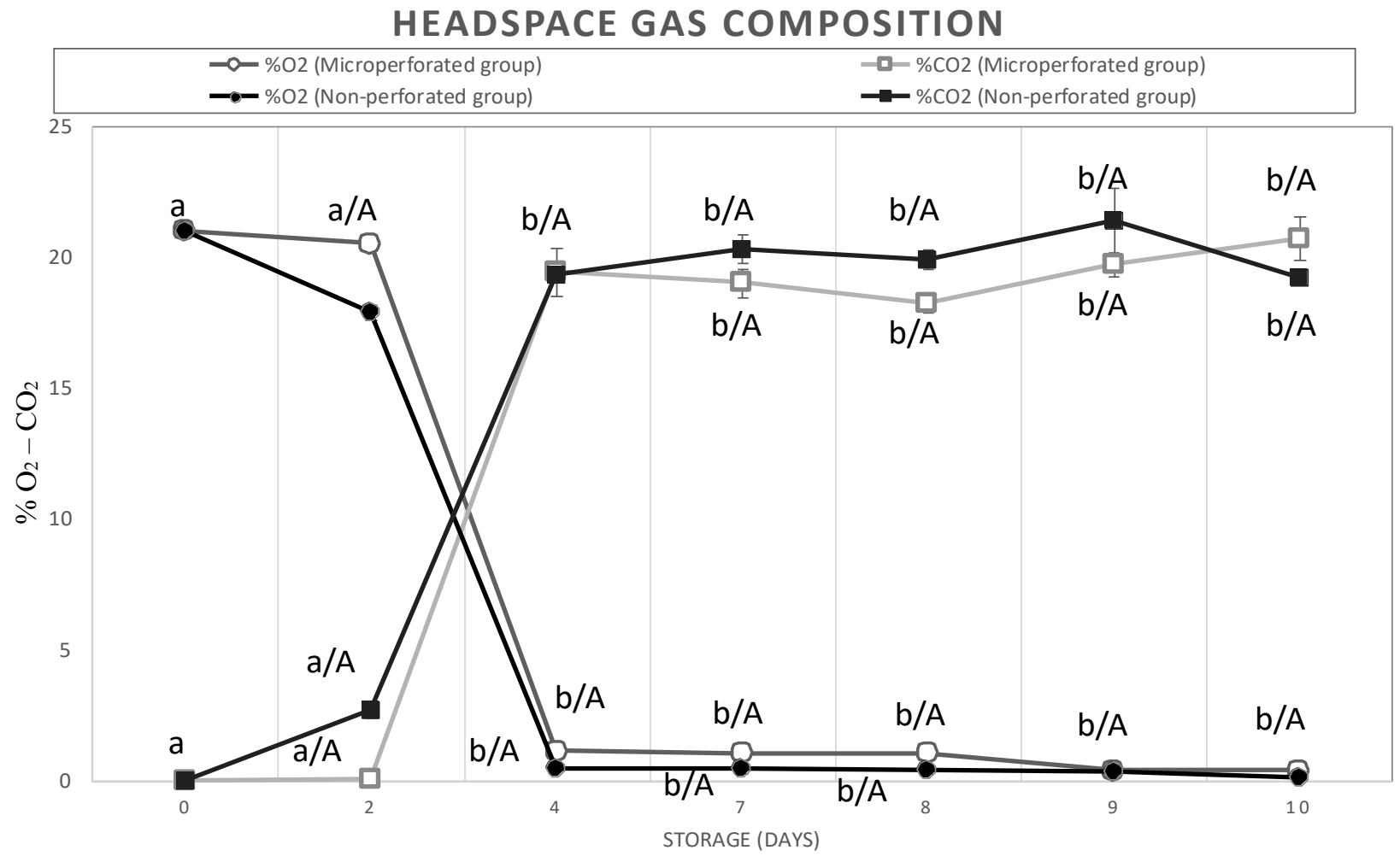

Figure 4 Headspace gas compositions of microperforated and nonperforated packages. Note: Different letters show the difference among the sample groups concerning the storage period. Different capital letters indicate the difference between the samples.

pH

The changes in the $\mathrm{pH}$ of the samples during the storage period were observed and the measurements were summarized in Table 1. No statistical difference could be detected among the samples in both groups concerning the storage period. The storage time and/or the microperforation process did not statistically affect the $\mathrm{pH}$ value. The $\mathrm{pH}$ values ranged from 6.69 to 6.92 and 6.86 in the non-perforated and microperforated samples respectively. These results are in agreement with those of several studies (Jaworska et al., 2010).
Over the 10 days of storage, the slight increase in the $\mathrm{pH}$ $(1.9 \%$ and $3.2 \%$ for microperforated and non-perforated respectively) of the mushrooms was also reported by several studies (Tao et al., 2006). On the other hand, in another study (Oliveira et al., 2012b), it was reported a slight decrease in the $\mathrm{pH}$ from 6.74 to 6.5 after 7 days of storage. However, the $\mathrm{pH}$ values of the control samples were slightly higher than those of microperforated samples. This result was also stated by several scientists (Gholami, Ahmadi and Farris, 2017). 
Table $1 \mathrm{pH}$ values of fresh-sliced mushrooms during the storage period.

\begin{tabular}{|c|c|c|c|c|c|c|c|}
\hline \multirow{2}{*}{ pH } & \multicolumn{7}{|c|}{ Storage period (days) } \\
\hline & $\mathbf{0}$ & 2 & 4 & 7 & 8 & 9 & 10 \\
\hline \multirow{2}{*}{ Microperforated } & 6.70 & 6.76 & 6.80 & 6.84 & 6.86 & 6.83 & 6.83 \\
\hline & $\pm 0.09^{\mathbf{a} / \mathbf{A}}$ & $\pm 0.04^{\mathrm{a} / \mathrm{A}}$ & $\pm 0.08^{\mathbf{a} / \mathbf{A}}$ & $\pm 0.03^{\mathbf{a} / \mathbf{A}}$ & $\pm 0.01^{\mathbf{a} / \mathbf{A}}$ & $\pm 0.01^{\mathrm{a} / \mathrm{A}}$ & $\pm 0.02^{\mathrm{a} / \mathrm{A}}$ \\
\hline \multirow[t]{2}{*}{ Non-perforated } & 6.70 & 6.84 & 6.93 & 6.95 & 6.91 & 6.92 & 6.92 \\
\hline & $\pm 0.09^{\mathbf{a} / \mathbf{A}}$ & $\pm 0.04^{\mathrm{a} / \mathrm{B}}$ & $\pm 0.04^{\mathrm{a} / \mathrm{B}}$ & $\pm 0.01^{\mathrm{a} / \mathbf{B}}$ & $\pm 0.01^{\mathrm{a} / \mathrm{B}}$ & $\pm 0.01^{\mathrm{a} / \mathbf{B}}$ & $\pm 0.01^{\mathrm{a} / \mathrm{B}}$ \\
\hline
\end{tabular}

Note: Different small letters show the difference among the sample groups for the storage period. Capital letters indicate the difference between the sample groups $(p \leq 0.05)$.

Table 2 Weight loss of fresh-sliced mushrooms during the storage period.

\begin{tabular}{|c|c|c|c|c|c|c|}
\hline \multirow{2}{*}{ Weight loss (\%) } & \multicolumn{6}{|c|}{ Storage period (days) } \\
\hline & 2 & 4 & 7 & 8 & 9 & 10 \\
\hline Microperforated & $\begin{array}{c}0.81 \\
\pm 0.01^{\mathrm{a} / \mathrm{A}}\end{array}$ & $\begin{array}{c}1.00 \\
\pm 0.08^{\mathbf{b} / \mathbf{A}}\end{array}$ & $\begin{array}{c}1.21 \\
\pm 0.11^{\mathbf{c} / \mathbf{A}}\end{array}$ & $1.60 \pm 0.01^{\mathrm{d} / \mathrm{A}}$ & $2.02 \pm 0.07^{\mathrm{e} / \mathbf{A}}$ & $2.80 \pm 0.11^{\mathbf{f} / \mathbf{A}}$ \\
\hline Non-perforated & $\begin{array}{c}1.22 \\
\pm 0.28^{\mathrm{a} / \mathbf{A}}\end{array}$ & $\begin{array}{c}1.34 \\
\pm 0.18^{\mathrm{a} / \mathbf{A}}\end{array}$ & $\begin{array}{c}1.62 \\
\pm 0.01^{\mathrm{a} / \mathbf{A}}\end{array}$ & $2.01 \pm 0.16^{\mathbf{a} / \mathbf{A}}$ & $3.2 \pm 0.65^{\mathbf{b} / \mathbf{A}}$ & $3.59 \pm 0.81^{\mathbf{b} / \mathbf{A}}$ \\
\hline
\end{tabular}

Note: Different small letters show the difference among the sample groups for the storage period. Capital letters indicate the difference between the sample groups $(p \leq 0.05)$.

Table 3 Color values of fresh-sliced mushrooms during the storage period.

\begin{tabular}{|c|c|c|c|c|c|c|c|}
\hline \multirow{2}{*}{ Color } & \multicolumn{7}{|c|}{ Storage period (days) } \\
\hline & $\mathbf{0}$ & 2 & 4 & 7 & 8 & 9 & 10 \\
\hline$\overline{\Delta E(M P)}$ & - & $9.59^{\mathbf{a} / \mathbf{A}}$ & $13.74^{\mathrm{ab} / \mathrm{A}}$ & $18.51^{\mathbf{b} / \mathbf{A}}$ & $25.26^{\mathbf{c} / \mathbf{A}}$ & $39.21^{\mathrm{d} / \mathbf{A}}$ & $42.53^{\mathrm{e} / \mathrm{A}}$ \\
\hline$\Delta \mathbf{E}(\mathbf{N P})$ & - & $17.89^{\mathbf{a} / \mathbf{B}}$ & $25.00^{\mathbf{b} / \mathbf{B}}$ & $23.32^{\mathbf{b} / \mathbf{B}}$ & $34.78^{\mathbf{c} / \mathbf{B}}$ & $45.11^{\mathrm{d} / \mathrm{B}}$ & $46.45^{\mathrm{e} / \mathrm{B}}$ \\
\hline BI (MP) & $19.86^{\mathbf{a} / \mathbf{A}}$ & $28.79^{\mathbf{b} / \mathbf{A}}$ & $31.94^{\mathrm{c} / \mathrm{A}}$ & $41.13^{\mathrm{d} / \mathrm{A}}$ & $48,12^{\mathrm{e} / \mathrm{A}}$ & $56.96^{\mathrm{f} / \mathrm{A}}$ & $70.96^{\mathrm{g} / \mathrm{A}}$ \\
\hline BI (NP) & $19.86^{\mathbf{a} / \mathbf{A}}$ & $34.30^{\mathbf{b} / \mathbf{B}}$ & $48.12^{\mathrm{c} / \mathbf{B}}$ & $50.44^{\mathrm{d} / \mathrm{B}}$ & $58.00^{\mathrm{e} / \mathbf{B}}$ & $78.79^{\mathbf{f} / \mathbf{B}}$ & $80.79^{\mathrm{g} / \mathrm{B}}$ \\
\hline $\mathrm{L}^{*}(\mathbf{M P})$ & $\begin{array}{c}86.18 \\
\pm 1.44^{\mathrm{a} / \mathrm{A}}\end{array}$ & $\begin{array}{c}77.40 \\
\pm 0.94^{\mathbf{b} / \mathbf{A}}\end{array}$ & $\begin{array}{c}73.06 \\
\pm 0.75^{\mathbf{c} / \mathbf{A}}\end{array}$ & $\begin{array}{c}69.18 \\
\pm 0.88^{\mathrm{d} / \mathrm{A}}\end{array}$ & $\begin{array}{c}61.03 \\
\pm 1.70^{\mathbf{e} / \mathbf{A}}\end{array}$ & $\begin{array}{c}47.42 \\
\pm 1.83^{\mathbf{f} / \mathbf{A}}\end{array}$ & $\begin{array}{c}44.41 \\
\pm 0.36^{\mathbf{f} / \mathbf{A}}\end{array}$ \\
\hline $\mathbf{L}^{*}(\mathbf{N P})$ & $\begin{array}{c}86.18 \\
\pm 1.44^{\mathrm{a} / \mathrm{A}}\end{array}$ & $\begin{array}{c}68.83 \\
\pm 2.28^{\mathbf{b} / \mathbf{B}}\end{array}$ & $\begin{array}{c}62.49 \\
\pm 0.23^{\mathbf{c} / \mathbf{B}}\end{array}$ & $\begin{array}{c}65.00 \\
\pm 0.94^{\mathrm{d} / \mathbf{B}}\end{array}$ & $\begin{array}{c}51.68 \\
\pm 1.19^{\mathrm{e} / \mathbf{B}}\end{array}$ & $\begin{array}{c}41.95 \\
\pm 0.32^{\mathbf{f} / \mathbf{B}}\end{array}$ & $\begin{array}{c}40.44 \\
\pm 0.71^{\mathbf{f} / \mathbf{B}}\end{array}$ \\
\hline
\end{tabular}

MP: Microperforated samples, NP: Non-perforated samples Note: Different small letters show the difference among the sample groups for the storage period. Capital letters indicate the difference between the sample groups $(p \leq 0.05)$.

\section{Weight loss}

The weight loss during the storage period has been considered as one of the main factors influencing the microbial spoilage of the mushrooms. Regardless of the type of packaging material, the spoilage proceeds along the storage period. For most of the fruits and vegetables, a weight loss of $5-6 \%$ indicates a significant reduction in their commercial value due to the spoilage (Guillame et al., 2010). The changes in the weight loss of the mushrooms stored in non-perforated and microperforated packaged samples were presented in Table 2.

As presented in Table 2., the weight loss in the nonperforated and microperforated mushrooms was below 5\% indicating that there was no decrease in the commercial value of the mushrooms during the storage period (Mahajan et al., 2007). Also, no significant difference was determined between the microperforated and nonperforated groups during each storage period. This result is in agreement with those of the previous research (El-Seifi et al., 2019). No statistical difference for the storage period could be detected among the non-perforated mushroom samples until the $9^{\text {th }}$ day of storage. On the other hand, a statistically significant difference was determined among the microperforated samples for each storage period $(p<0.05)$. The weight loss on the $10^{\text {th }}$ day of the storage period was lower in the microperforated mushrooms $(2.80 \%)$ than that of the non-perforated samples (3.59\%). The scientists (El-Seifi et al., 2019) also reported a similar result for the dill in PP packages with 8 microholes of diameter $(40 \mu \mathrm{m})$ after 7 days at $0{ }^{\circ} \mathrm{C}$ plus 4 days at $10^{\circ} \mathrm{C}$ storage.

\section{Color}

The Hunter $\mathrm{Lab}\left(\mathrm{L}^{*}, \mathrm{BI}\right.$, and $\Delta \mathrm{E}$ ) values of the nonperforated and microperforated fresh-sliced mushroom samples were shown in Table 3. As presented in Table 3., the $\mathrm{L}^{*}$ values tended to decrease throughout the entire storage period in both groups of samples (non-perforated and microperforated). The results are consistent with the data of some other studies (Oliveira et al., 2012b; Gholami, Ahmadi and Farris, 2017). The $L^{*}$ values appeared to be higher in the microperforated samples than those of the non-perforated ones. This issue was evident for the undesired browning reactions that might have taken place in the non-microperforated samples. For all storage periods examined in this study, there was a statistical significance between the microperforated and nonperforated groups in the $\mathrm{L}^{*}, \mathrm{BI}$, and $\Delta \mathrm{E}$ values $(p<0.05)$. The most important factor which might have an impact on the customer preferences for the mushrooms 
(Agaricus bisporus) is to be considered as the appearance and the browning in the tissue after being harvested. The enzymatic activities and microbial contamination might be responsible for the browning on the surface of the mushrooms (Nerya et al., 2006). Hence, the total color difference $(\Delta \mathrm{E})$, the lightness $\left(\mathrm{L}^{*}\right)$, and the browning index (BI) have been regarded as the most critical parameters during the storage and the changes in these values were presented in Table 3.

As presented in Table 3., the browning index and the total color difference values for both samples increased throughout the 10 day storage period. The $\mathrm{L}^{*}$ values decreased considerably along the storage period in both groups. However, the $\mathrm{L}^{*}$ values of non-perforated samples were lower compared to those of the microperforated ones during all storage periods. The difference in the $\mathrm{L}^{*}$ values between microperforated and non-perforated samples was found statistically significant for each period $(p<0.05)$. The BI values of both groups increased during the entire storage period. However, a statistically significant difference between the two groups was detected in all storage periods $(p<0.05)$. BI values were determined as 70.96 and 80.79 and $\Delta \mathrm{E}$ values were determined as 42.53 and 46.45 for microperforated and non-perforated samples respectively on the $10^{\text {th }}$ day of storage. BI values increased approximately by $257 \%$ and $307 \%$ since the beginning of the storage. In several studies (Oliveira et al., 2012b; Pogorzelska-Nowicka et al., 2020) such an increase in the BI values was observed along the storage period. The browning index and total color difference values of the microperforated samples were lower than compared to those of the non-perforated samples which might be associated with the microbial spoilage and enzymatic reactions that started earlier in the non-perforated samples. Several authors (Lin et al., 2017) reported that high $\mathrm{CO}_{2}$ concentration might give rise to damage in the cap surface tissue of the mushrooms which also stimulates the browning and leads to higher $\mathrm{BI}$ values. On the $4^{\text {th }}$ day, the $\mathrm{CO}_{2}$ concentrations in the package were close to $20 \%$ for microperforated and non-perforated packages. Hence, the increase in the $\mathrm{BI}$ values might be associated with the rise in the $\mathrm{CO}_{2}$ concentration.

\section{Hardness}

The textural characteristics of the mushrooms can be harshly influenced due to enzymatic activity and water loss during storage (Gholami, Ahmadi and Farris, 2017). Loss of turgor and softening of the tissues were reported as the main causes of the poor textural quality in the mushrooms by several authors (Guillame et al., 2010; Liu et al., 2010; Khan et al., 2014; Qin et al., 2015). The hardness is the most common feature used for the description of quality attributes for the button mushrooms (Agaricus bisporus). The higher the hardness, the better the sensory properties of the mushrooms (Gholami, Ahmadi and Farris, 2017). The changes in the hardness of the fresh-sliced mushrooms in the nonperforated and microperforated packaging films during the storage were presented in Table 4.

The aging process, the loss in the tissue hardness, and the overripening of the mushrooms lead to tissue softening characterized by a spongious texture (Villaescusa and Gil Muñoz, 2003). As expected, the hardness values of both groups of samples declined throughout the storage period. As shown in Table 4, no statistically significant changes in the hardness values of the microperforated samples could be observed during the first four days of storage. On the other hand, the decrease in the hardness values of non-perforated samples was higher than in those of the microperforated ones during each storage period. Therefore, one might state that the softening process occurred more obviously in the non-perforated samples. This result might be evident for the beneficiary effect of microperforation in terms of the retardation of tissue softening.

After 10 days of storage, the decline in the hardness was approximately $38 \%$ and $66 \%$ for the microperforated and non-perforated samples respectively. The loss in the hardness might be associated with the loss of cell urgency caused by the cell disruption, intercellular expansion of the pileal surface (Zivanovic, Buescher and Kim, 2000), the protein and polysaccharide degradation which also affect the cell permeability (Oliveira et al., 2012a). In the study (Pogorzelska-Nowicka et al., 2020), it was reported a higher decline $(72.5 \%)$ in the firmness of the mushrooms in perforated packages after 7 days of storage at $15^{\circ} \mathrm{C}$. They used a macro-perforation design with 6 holes of a diameter of 330 microns which could allow more tissue softening due to the higher transmission rates of oxygen as a result of wider surface area.

\section{Microbiological analysis}

Investigation of the pathogenic microorganisms was carried out at the beginning of the storage (day 0 ).

Table 4 Hardness values of fresh-sliced mushrooms during the storage period.

\begin{tabular}{ccc}
\hline \multirow{2}{*}{\begin{tabular}{c} 
Storage period \\
\cline { 2 - 3 } (Day)
\end{tabular}} & Hardness $\mathbf{( g )}$ & Non-perforated \\
\hline $\mathbf{0}$ & $34351.87 \pm 1031.40^{\mathbf{a} / \mathbf{A}}$ & $34351.87 \pm 1031.40^{\mathbf{a} / \mathbf{A}}$ \\
$\mathbf{2}$ & $33458.6 \pm 178.42^{\mathbf{a} / \mathbf{A}}$ & $26519.53 \pm 300.25^{\mathbf{b} / \mathbf{B}}$ \\
$\mathbf{4}$ & $33215.47 \pm 531.52^{\mathbf{a} / \mathbf{A}}$ & $25290.98 \pm 170.80^{\mathbf{b c /} / \mathbf{B}}$ \\
$\mathbf{7}$ & $28276.83 \pm 565.52^{\mathbf{b} / \mathbf{A}}$ & $25184.28 \pm 1003.84^{\mathbf{b c} / \mathbf{B}}$ \\
$\mathbf{8}$ & $27770.93 \pm 797.67^{\mathbf{b} / \mathbf{A}}$ & $24343.85 \pm 1286.35^{\mathbf{c} / \mathbf{B}}$ \\
$\mathbf{9}$ & $21797.1 \pm 472.70^{\mathbf{c} / \mathbf{A}}$ & $19599 \pm 266.04^{\mathbf{d} / \mathbf{B}}$ \\
$\mathbf{1 0}$ & $21368.83 \pm 460.99^{\mathbf{c} / \mathbf{A}}$ & $11678.33 \pm 208.50^{\mathbf{e} / \mathbf{B}}$ \\
\hline
\end{tabular}

Note: Different small letters show the difference among the sample groups for the storage period. Capital letters indicate the difference between the sample groups $(p \leq 0.05)$. 
TAMB and Pseudomonas spp.

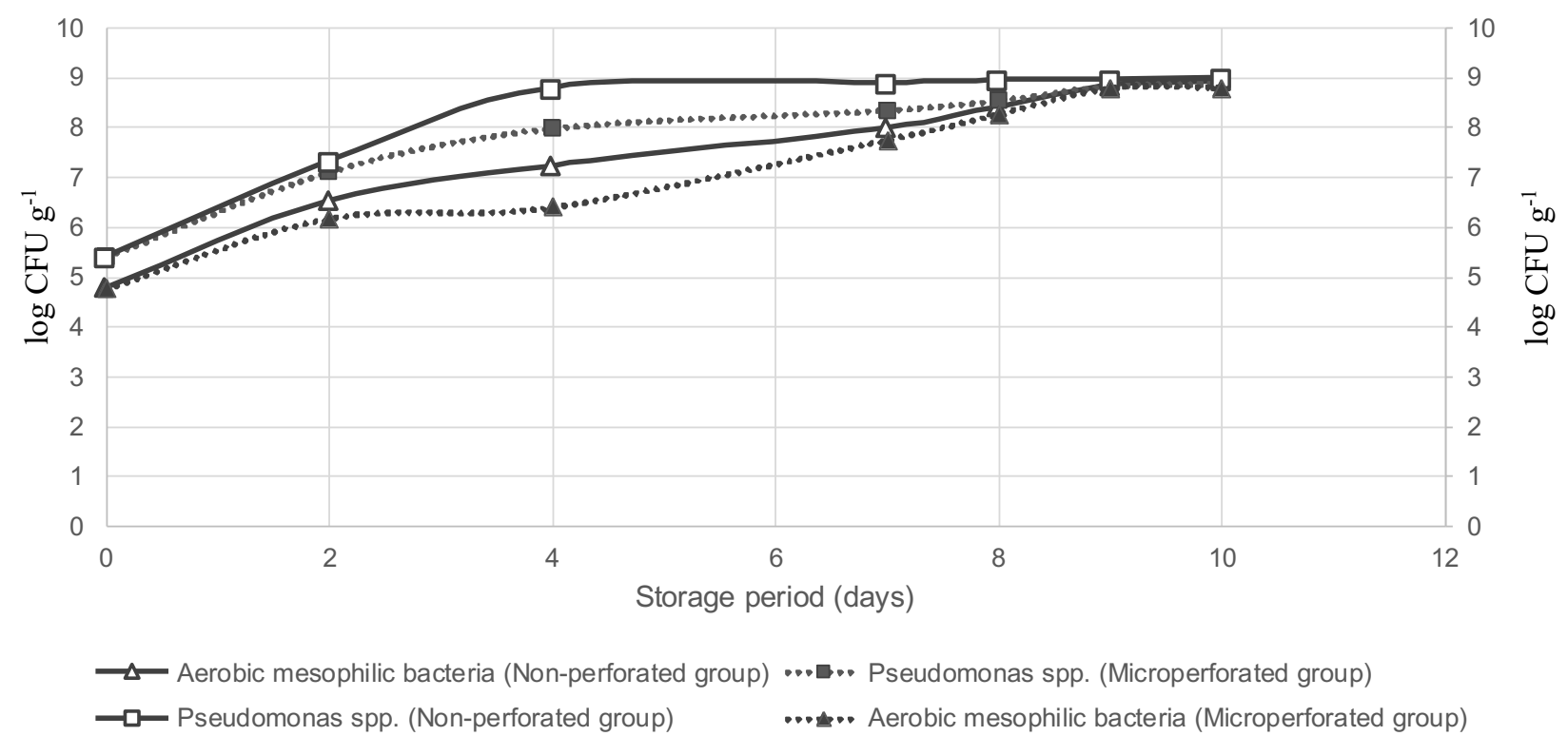

Figure 5 Count of Total aerobic mesophilic bacteria and Pseudomonas spp. (log CFU g ${ }^{-1}$ ) of fresh-sliced mushrooms during the storage period.

No pathogenic microorganisms were detected in the freshsliced mushroom samples.

The shelf life of the mushrooms was severely influenced by the growth of total aerobic mesophilic bacteria and Pseudomonas spp. Thus, analysis of the total aerobic mesophilic bacteria count and Pseudomonas spp. counts were performed along with the shelf life. The results were presented in Figure 5.

As shown in Figure 5, since the initial microbial load was over $5 \log \mathrm{CFU}_{\mathrm{g}^{-1}}$ the number of total microorganisms rapidly increased during the first days of storage. The total count of Pseudomonas spp. increased from 5.40 (day 0) to $8.88 \log$ CFU.g ${ }^{-1}$ in the microperforated packaged samples at the end of the storage period (day 10), while a quite rapid increase in the number of Pseudomonas spp. was observed in the non-perforated packaged samples on the $4^{\text {th }}$ day by reaching a value of $8.78 \log \mathrm{CFU} \cdot \mathrm{g}^{-1}$. On the other hand, the TAMB count increased more slowly compared to the count of Pseudomonas spp. and reached in the microperforated and non-perforated packaged samples $8.79 \log$ CFU.g ${ }^{-1}$ and $8.92 \log$ CFU. $\mathrm{g}^{-1}$ respectively at the end of the storage. On the other hand, the TAMB count increased more slowly compared to the count of Pseudomonas spp. and reached in the microperforated and non-perforated packaged samples $8.79 \log . \mathrm{CFU} \mathrm{g} \mathrm{g}^{-1}$ and $8.92 \mathrm{log}$ CFU.g ${ }^{-1}$ at the end of the storage. The studies concerning the determination of the shelf life of the fresh-sliced mushrooms reported similar results to our findings and revealed that Pseudomonas spp. was regarded as one of the main factors leading to microbial spoilage of mushrooms (Gonzalez-Fandos et al., 2000; Srivastava et al., 2010; Wang et al., 2017). Unfortunately, no legislative regulation specific to the microbial spoilage is available about the fresh-cut produce except for the pathogenic microorganisms. However, basically above the level of $8 \log$ CFU.g ${ }^{-1}$ can be considered as the inception of deterioration, even though no risks in terms of food safety might arise at this level and it is important for food quality because Pseudomonas spp. are saprophytic microorganisms that lead to deterioration in mushrooms. As a result of the microbial spoilage, several qualitative defects such as changes in color, undesired odor, and softening might be encountered which affect the consumer demand (Simón, González-Fandos and Tobar, 2005). Based on the counts of Pseudomonas spp. and TAMB, we can conclude that the microbial deterioration started on the $7^{\text {th }}$ day of storage in the microperforated packaged samples whereas it started on the $4^{\text {th }}$ day of storage in the non-perforated packaged samples. Tissue softening due to microbial spoilage and/or drip loss occurred in the microperforated packaged samples on the $7^{\text {th }}$ day according to the hardness values. On the other hand, there was a remarkable decrease in the hardness in the non-perforated samples on the $2^{\text {nd }}$ day.

\section{Sensory evaluation}

The changes in the sensory characteristics of the samples during storage were presented in Table 5.

As summarized in Table 5, the scores of the odor, texture, appearance, and overall acceptability decreased with the storage period for each group of samples. However, the scores for the sensorial attributes of the microperforated packaged samples were higher than the non-perforated packaged samples. The sensorial attributes were maintained for microperforated packaged samples until the $9^{\text {th }}$ day of storage and on this period the sensorial scores were below 3 which is the limiting value to accept the food in 5 points hedonic scale for the sensorial attributes. 
Table 5 Sensory evaluation of fresh-sliced mushrooms during the storage period.

\begin{tabular}{ccccccccc}
\hline \multirow{2}{*}{$\begin{array}{c}\text { Storage period } \\
\text { (Day) }\end{array}$} & \multicolumn{9}{c}{ Texture } & \multicolumn{9}{c}{ Odor } & \multicolumn{2}{c}{ Appearance } & \multicolumn{2}{c}{ Overall Accept. } \\
\cline { 2 - 9 } & $\mathbf{M P}$ & $\mathbf{N P}$ & $\mathbf{M P}$ & NP & MP & NP & MP & NP \\
\hline $\mathbf{0}$ & $5.0 \pm 0.00$ & $5.0 \pm 0.00$ & $5.0 \pm 0.00$ & $5.0 \pm 0.00$ & $5.0 \pm 0.00$ & $5.0 \pm 0.00$ & $5.0 \pm 0.00$ & $5.0 \pm 0.00$ \\
$\mathbf{2}$ & $4.6 \pm 0.49$ & $4.2 \pm 0.40$ & $4.4 \pm 0.49$ & $3.8 \pm 0.75$ & $4.8 \pm 0.40$ & $3.8 \pm 0.75$ & $5.0 \pm 0.00$ & $3.8 \pm 0.40$ \\
$\mathbf{4}$ & $4.6 \pm 0.80$ & $\mathbf{4 . 2} \pm \mathbf{0 . 4 0}$ & $4.2 \pm 0.40$ & $\mathbf{4 . 0} \pm \mathbf{0 . 8 9}$ & $4.2 \pm 0.40$ & $\mathbf{3 . 0} \pm \mathbf{0 . 6 3}$ & $4.4 \pm 0.49$ & $\mathbf{3 . 6} \pm \mathbf{0 . 8 0}$ \\
$\mathbf{7}$ & $4.2 \pm 0.40$ & $2.8 \pm 0.75$ & $4.0 \pm 0.89$ & $2.4 \pm 0.49$ & $3.4 \pm 0.63$ & $2.4 \pm 0.49$ & $3.6 \pm 0.80$ & $2.6 \pm 0.49$ \\
$\mathbf{8}$ & $\mathbf{3 . 2} \pm \mathbf{0 . 4 0}$ & $2.2 \pm 0.40$ & $\mathbf{3 . 4} \pm \mathbf{0 . 8 0}$ & $2.4 \pm 0.80$ & $\mathbf{3 . 0} \pm \mathbf{0 . 4 9}$ & $2.2 \pm 0.40$ & $\mathbf{3 . 4} \pm \mathbf{0 . 8 0}$ & $2.2 \pm 0.40$ \\
$\mathbf{9}$ & $2.2 \pm 0.98$ & $1.4 \pm 0.49$ & $2.4 \pm 0.49$ & $1.6 \pm 0.80$ & $2.8 \pm 0.40$ & $1.6 \pm 0.49$ & $2.8 \pm 0.40$ & $1.6 \pm 0.49$ \\
$\mathbf{1 0}$ & $2.2 \pm 0.40$ & $1.2 \pm 0.40$ & $2.2 \pm 0.40$ & $1.4 \pm 0.80$ & $2.2 \pm 0.40$ & $1.2 \pm 0.40$ & $2.2 \pm 0.40$ & $1.4 \pm 0.80$ \\
\hline
\end{tabular}

Note: MP: Perforated samples NP: Nonperforated samples. Different small letters show the difference among the sample groups for the storage period. Capital letters indicate the difference between the sample groups $(p \leq 0.05)$.

Hhowever the sensorial properties of non-perforated packaged samples were acceptable until the $4^{\text {th }}$ day of storage. Since we couldn't analyze on the $5^{\text {th }}$ or $6^{\text {th }}$ day of the storage, it is not clear if the non-perforated packaged samples were acceptable or not on these days. However the non-perforated packaged samples weren't accepted because of their poor sensorial attributes all including texture, odor, appearance, and overall acceptance on the $7^{\text {th }}$ day of storage. For this reason, it is not clear whether the non-perforated packaged samples were acceptable or not after the $4^{\text {th }}$ day of storage. Several scientists (Eastwood and Burton, 2002) reported that the consumers mostly prefer the mushrooms with fewer spots and better appearance even though the aged mushrooms have a better taste. Thus, the overall acceptability of the consumers depends much more on the color, texture, and appearance than the flavor of the mushrooms. Based on the sensorial properties, we can conclude that the shelf life of fresh-sliced mushrooms can be extended to 8 days with microperforated packaging. Whereas the shelf life of fresh-sliced mushrooms was less than 7 days $(4,5$, or 6 days). It was shown that the microperforation process was effective to keep the sensorial properties and extending the shelf life of fresh-sliced mushrooms as stated by (Dhalsamant et al., 2015).

\section{CONCLUSION}

The microperforation process of BOPP films extended the shelf life of the fresh-sliced mushrooms concerning the nonperforated packaged samples. The shelf life of the freshsliced mushrooms in microperforated packaging material of BOPP was 8 days seasonally. Although the microbial deterioration starts on the $7^{\text {th }}$ day of the storage period in the microperforated packaged samples, these samples were evaluated as acceptable for their sensorial attributes on the $8^{\text {th }}$ day of the storage period. The shelf life of the nonperforated packaged fresh-sliced mushrooms was determined to be less than 7 days $(4,5$, or 6 days) based on the sensorial evaluation since their sensorial scores were above 3 on the $4^{\text {th }}$ day and below 3 on the $7^{\text {th }}$ day of the storage period.

The design of the microholes in the perforation process becomes crucial since the number and diameter of the holes are effective on the respiration rate and hence the shelf life of the fresh-sliced mushrooms. The empirical formula was based on elliptic dimensions of $40 \times 30 \mu \mathrm{m}$ and $350 \times 110 \mu \mathrm{m}$ which was a unique radial and comparatively smaller dimension in our experiments. Thus, the OTR was calculated using this diameter. To obtain more accurate results an estimation by extrapolation of this value to fit in the empirical formula ought to be performed. This evaluation would promise to the scientists to create more effective and novel designs of microperforated packaging materials in the future which might also prolong the shelf life of other foods.

\section{REFERENCES}

Almenar, E., Del Valle, V., Hernandez-Munoz, P., Lagaron, J. M., Catala, R., Gavara, R. 2007. Equilibrium of modified atmosphere packaging of wild strawberries. Journal of the Science of Food and Agriculture, vol. 87, no. 10, p. 1931-1939. https://doi.org/10.1002/jsfa.2938

ASTM D3985. 2017. Standard Test Method for Oxygen Gas Transmission Rate Through Plastic Film and Sheeting Using a Coulometric Sensor. Annual book of ASTM standards. Philadelphia, US : American Society for Testing and Materials, 7 p. https://doi.org/10.1520/D3985-17

ASTM F1249. 2020. Standard Test method for Water Vapor Transmission Rate Through Plastic Film and Sheeting Using a Modulated Infrared Sensor. Philadelphia, US : American Society for Testing and Materials, $6 \mathrm{p}$. https://doi.org/10.1520/F1249-20

Brennan, M. H., Gormley, R. T. 1998. Extending the shelf life of fresh sliced mushrooms. The National Food Centre, Dublin : Research Report No: 2, 30 p. ISBN 1901138402.

Brody, A. L. 2005. What's fresh about fresh-cut. Food Technology, vol. 59, no. 1, p. 74-77.

Cliff, M. A., Toivonen, P. M., Forney, C. F., Lu, C. 2010. Quality of fresh-cut apple slices stored in solid and microperforated film packages having contrasting $\mathrm{O} 2$ headspace atmospheres. Postharvest Biology and Technology, vol. 58, no. 3, p. 254-261. https://doi.org/10.1016/j.postharvbio.2010.07.015

De Reuck, K., Sivakumar, D., Korsten, L. 2009. Effect of passive and active modified atmosphere packaging on quality retention of two cultivars of litchi (Litchi chinensis Sonn.). Journal of Food Quality, vol. 33, no. 1, p. 337-351. https://doi.org/10.1111/j.1745-4557.2010.00335.x

Dhalsamant, K., Dash, S. K., Bal, L. M., Panda, M. K. 2015. Effect of perforation mediated MAP on shelf life of mushroom (Volvariella volvacea). Scientia Horticulturae, vol. 189, p. 4150. https://doi.org/10.1016/j.scienta.2015.03.027

Eastwood, D., Burton, K. 2002. Mushrooms-a matter of choice and spoiling oneself. Microbiology Today, vol. 29, p. 18-23. https://doi.org/10.1111/1467-8322.00102 
El-Seifi, S. K., El-Bassiouny, R. E. I., Nasef, I. N., Hamada, T. H. 2019. Extending storage period and shelf life and maintaining quality of dill using microperforated polypropylene packages. Zagazig Journal of Agricultural Research, vol. 46, no. 2, p. 341-356. https://doi.org/10.21608/zjar.2019.33390

Fonseca, S. C., Oliveira, F. A., Brecht, J. K. 2002. Modelling respiration rate of fresh fruits and vegetables for modified atmosphere packages: a review. Journal of Food Engineering, vol. 52, no. 2, p. 99-119. https://doi.org/10.1016/S02608774(01)00106-6

Forney, C. F., Yaganza, E. S. 2011. Fresh-cut produce packaging and the use of biaxial stretched films. In DeMeuse, M. T. Biaxial Stretching of Film. Cambridge, UK : Woodhead Publishing, p. 143-164. ISBN 978-1-84569-675-7. https://doi.org/10.1533/9780857092953.2.143

Gholami, R., Ahmadi, E., Farris, S. 2017. Shelf life extension of white mushrooms (Agaricus bisporus) by low temperatures conditioning, modified atmosphere, and nanocomposite packaging material. Food Packaging and Shelf Life, vol. 14, p. 88-95. https://doi.org/10.1016/j.fpsl.2017.09.001

González, J., Ferrer, A., Oria, R., Salvador, M. L. 2008. Determination of $\mathrm{O} 2$ and $\mathrm{CO} 2$ transmission rates through microperforated films for modified atmosphere packaging of fresh fruits and vegetables. Journal of Food Engineering, vol. 86, no. $2, \quad$ p. $194-201$. https://doi.org/10.1016/j.jfoodeng.2007.09.023

Gonzalez-Buesa, J., Ferrer-Mairal, A., Oria, R., Salvador, M. L. 2009. A mathematical model for packaging with microperforated films of fresh-cut fruits and vegetables. Journal of Food Engineering, vol. 95, no. 1, p. 158-165. https://doi.org/10.1016/j.jfoodeng.2009.04.025

Gonzalez-Fandos, E., Olarte, C., Giménez, M., Sanz, S., Simón, A. 2001. Behavior of Listeria monocytogenes in packaged fresh mushrooms (Agaricus bisporus). Journal of Applied Microbiology, vol. 91, no. 5, p. 795-805. https://doi.org/10.1046/j.1365-2672.2001.01452.x

Gonzalez-Fandos, M., Giménez, C., Olarte, Sanz, S., Simón, A. 2000. Effect of packaging conditions on the growth of microorganisms and the quality characteristics of fresh mushrooms (Agaricus bisporus) stored at inadequate temperatures. Journal of Applied Microbiology, vol. 89, no. 4, p. 624-632. https://doi.org/10.1046/j.1365-2672.2000.01159.x

Guillame, C., Schwab, I., Gastaldi, E., Gontard, N. 2010. Biobased packaging for improving preservation of fresh common mushrooms (Agaricus bisporus L.). Innovative Food Science and Emerging Technologies, vol. 11, no. 4, p. 690-696. https://doi.org/10.1016/j.ifset.2010.05.007

Hussein, Z., Caleb, O. J., Opara, U. L. 2015. Perforationmediated modified atmosphere packaging of fresh and minimally processed produce-A review. Food Packaging and Shelf Life, vol. 6, p. 7-20. https://doi.org/10.1016/j.fps1.2015.08.003

IBM Corp. 2013. IBM SPSS Statistics for windows, Version 22.0. Armonk, NY : IBM Corp.

Iqbal, T., Rodrigues, F. A. S., Mahajan, P. V., Kerry, J. P. 2009. Effect of time, temperature, and slicing on respiration rate of mushrooms. Journal of Food Science, vol. 74, no. 6, p. 298-303. https://doi.org/10.1111/j.1750-3841.2009.01198.x

ISO 13720. 2010. Meat and meat products-Enumeration of presumptive Pseudomonas spp.

ISO 4833-1. 2013. Microbiology of the food chainHorizontal method for the enumeration of microorganismsPart 1: Colony count at $30^{\circ} \mathrm{C}$ by the pour plate technique.

Jaworska G., Bernas, E., Biernacka, A., Maciejaszek, I. 2010. Comparison of the texture of fresh and preserved Agaricus bisporus and Boletus edulis mushrooms. International Journal of Food Science and Technology, vol. 45, no. 8, p. 1659-1665. https://doi.org/10.1111/j.1365-2621.2010.02319.x

Kader, A. A. 1986. Biochemical and physiological basis for effects of controlled and modified atmospheres on fruits and vegetables. Food technology, vol. 40, p. 99-104.

Kamal, A. S. M., Khair, A., Begum, F., Chowdhury, K., Karim, R. 2015. Effect of respiratory gases (O2 ; CO2) on shelf life of fresh oyster mushrooms packaged with different sealable polymeric materials. Bangladesh Journal of Scientific and Industrial Research, vol. 50 no. 3, p. 205-210. https://doi.org/10.3329/bjsir.v50i3.25587

Khan, Z. U., Aisikaer, G., Khan, R. U., Bu, J., Jiang, Z., Ni, Z., Ying, T. 2014. Effect of composite chemical pretreatment on maintaining quality of button mushroom (Agaricus bisporus) during postharvest storage. Postharvest Biology and Technology, vol. 95, p. 36-41. https://doi.org/10.1016/j.postharvbio.2014.04.001

Lee, J. S. 1999. Effects of modified atmosphere packaging on the quality of chitosan and $\mathrm{CaCl} 2$ coated mushroom (Agaricus bisporus). Korean Journal of Food Science and Technology, vol. 31, no. 5, p. 1308-1314.

Lin, Q., Lu, Y., Zhang, J., Liu, W., Guan, W., Wang, Z. 2017. Effects of high CO2 in-package treatment on flavor, quality and antioxidant activity of button mushroom (Agaricus bisporus) during postharvest storage. Postharvest Biology and Technology, vol. 123, p. 112-118. https://doi.org/10.1016/j.postharvbio.2016.09.006

Liu, Z., Wang, X., Zhu, J., Wang, J. 2010. Effect of high oxygen modified atmosphere on postharvest physiology and sensorial qualities of mushroom. International Journal of Food Science and Technology, vol. 45, no. 6, p. 1097-1103. https://doi.org/10.1111/j.1365-2621.2010.02199.x

Mahajan, P. V., Oliveira, F. A. R., Montanez, J. C., Frias, J. 2007. Development of user-friendly software for design of modified atmosphere packaging for fresh and fresh-cut produce. Innovative Food Science and Emerging Technologies, vol. 8, no. 1, p. 84-92. https://doi.org/10.1016/j.ifset.2006.07.005

Mau, J. L., Miklus, M. B., Beelman, R. B. 1993. The shelf life of Agaricus mushrooms. Developments In Food Science, vol. 33, p. 255.

Nerya, O., Ben-Arie, R., Luzzatto, T., Musa, R., Khativ, S., Vaya, J. 2006. Prevention of Agaricus bisporus postharvest browning with tyrosinase inhibitors. Postharvest Biology and Technology, vol. 39, no. 3, p. 272-277. https://doi.org/10.1016/j.postharvbio.2005.11.001

Oliveira, F. A. R., Fonseca, S. C., Oliveira, J. C., Brecht, J. K., Chau, K. V. 1998. Development of perforation-mediated modified atmosphere packaging to preserve fresh fruit and vegetable quality after harvest/Envasado em atmosfera modificada y peliculas perforadas para preservar la calidad de frutas y verduras frescas despues de su cosecha. Food Science and Technology International, vol. 4, no. 5, p. 339-352. https://doi.org/10.1177/108201329800400506

Oliveira, F., Sousa-Gallagher, M. J., Mahajan, P. V., Teixeira, J. A. 2012a. Evaluation of MAP engineering design parameters on quality of fresh-sliced mushrooms. Journal of Food Engineering, vol. 108, no. 4, p. 507-514. https://doi.org/10.1016/j.jfoodeng.2011.09.025

Oliveira, F., Sousa-Gallagher, M. J., Mahajan, P. V., Teixeira, J. A. 2012b. Development of shelf life kinetic model for modified atmosphere packaging of fresh sliced mushrooms. Journal of Food Engineering, vol. 111, no. 2, p. 466-473. https://doi.org/10.1016/j.jfoodeng.2012.01.013 
Parentelli, C., Ares, G., Corona, M., Lareo, C., Gámbaro, A., Soubes, M., Lema, P. 2007. Sensory and microbiological quality of shiitake mushrooms in modified-atmosphere packages. Journal of the Science of Food and Agriculture, vol. 87, no. 9, p. 1645-1652. https://doi.org/10.1002/jsfa.2848

Pogorzelska-Nowicka, E., Hanula, M., WojtasikKalinowska, I., Stelmasiak, A., Zalewska, M., Półtorak, A., Wierzbicka, A. 2020. Packaging in a high O2 or air atmospheres and in microperforated films effects on quality of button mushrooms stored at room temperature. Agriculture, vol. $10, \quad$ no. $10, \quad$ p. 479 . https://doi.org/10.3390/agriculture10100479

Qin, Y., Liu, D., Wu, Y., Yuan, M., Li, Y., Yang, J. 2015. Effect of PLA/PCL/cinnamaldehyde packaging on physiochemical and microbial quality of button mushroom (Agaricus bisporus). Postharvest Biology and Technology, vol. 99, p.

73-79.

https://doi.org/10.1016/j.postharvbio.2014.07.018

Rivera, C. S., Blanco, D., Salvador, M. L., Venturini, M. E. 2010. Shelf-life extension of fresh Tuber aestivum and Tuber melanosporum truffles by modified atmosphere packaging with microperforated films. Journal of Food Science, vol. 75, no. 4 , p. 225-233. https://doi.org/10.1111/j.17503841.2010.01602.x

Simón, A., González-Fandos, E., Tobar, V. 2005. The sensory and microbiological quality of fresh sliced mushroom (Agaricus bisporus L.) packaged in modified atmospheres. Journal of Food Science and Technology, vol. 40, no. 9, p. 943952. https://doi.org/10.1111/j.1365-2621.2005.01028.x

Singh, P., Langowski, H. C., Wani, A. A., Saengerlaub, S. 2010. Recent advances in extending the shelf life of fresh Agaricus mushrooms: a review. Journal of the Science of Food and Agriculture, vol. 90, no. 9, p. 1393-1402. https://doi.org/10.1002/jsfa.3971

Srivastava, A., Singh, A. Raja, R. B., Arunachalam, K. D. 2010. Shelf life extension of fresh Mushrooms (Agaricus bisporus) by application of tomato paste. International Journal of Engineering Science and Technology, vol. 2, no. 5, p. 783-786.

Tao, F., Zhang, M., Yu, H., Sun, J. 2006. Effects of different storage conditions on chemical and physical properties of white mushrooms after vacuum cooling. Journal of Food Engineering, vol. 77, no. 3, p. 545-549. https://doi.org/10.1016/j.jfoodeng.2005.06.069

Toivonen, P. M., Brandenburg, J. S., Luo, Y. 2019. Modified atmosphere packaging for fresh-cut produce. In Yahia, E. M. Modified and controlled atmospheres for the storage, transportation, and packaging of horticultural commodities. 1st ed. Boca Raton, USA : CRC press, p. 463-489. ISBN 9780367385897.

Villaescusa, R. Gil Muñoz, M. I. 2003. Quality improvement of Pleurotus mushrooms by modified atmosphere packaging and moisture absorbers. Postharvest Biology and Technology, vol. 28, no. 1, p. 169-179. https://doi.org/10.1016/S09255214(02)00140-0

Wang, J., Chen, J., Hu, Y., Hu, H., Liu, G., Yan, R. 2017. Application of a predictive growth model of Pseudomonas spp. for estimating shelf life of fresh Agaricus bisporus. Journal of food protection, vol. 80, no. 10, p. 1676-1681. https://doi.org/10.4315/0362-028X.JFP-17-055

Warwick, M. G., Tsureda, A. 1997. The interaction of the soft rot bacterium Pseudomonas gladroli pv. agaricicoa with Japanese cultivated mushrooms. Canadian Journal of
Microbiology, vol. 43, no. 7, p. 639-648. https://doi.org/10.1139/m97-091

Zivanovic, S, Buescher, R. W., Kim, K. S. 2000. Textural changes in mushrooms (Agaricus bisporus) associated with tissue ultrastructure and composition. Journal of Food Science, vol. 65, no. 8, p. 1404-1408. https://doi.org/10.1111/j.13652621.2000.tb10621.x

Funds:

This project was funded by TUBITAK (Scientific and Technological Research Council of Turkey) with the project number of 2209-B.

\section{Acknowledgments:}

We would like to thank you to Laseral Industrial Laser Systems Company (Laseral Endüstriyel Lazer Sistemleri San. ve Tic. Ltd. Şti.) Bornova, Izmir for their valuable assistance in performing laser microperforation process.

\section{Conflict of Interest:}

The authors declare no conflict of interest.

\section{Ethical Statement:}

This article does not contain any studies that would require an ethical statement.

\section{Contact Address:}

*Özlem Kizilirmak Esmer, Ege University, Engineering Faculty, Food Engineering Department, 35030, Bornova, İzmir, Turkey,

E-mail: ozlem.kizilirmak@ege.edu.tr

ORCID: https://orcid.org/0000-0003-4652-0514

Erinç Koçak, Ege University, Engineering Faculty, Food Engineering Department, 35030, Bornova, Izmir, Turkey,

E-mail: erinckocak@gmail.com

ORCID: https://orcid.org/0000-0001-9054-4703

Aslı Şahiner, Ege University, Science Faculty, Biology Department, 35030, Bornova, Izmir, Turkey,

E-mail: aslisahiner@gmail.com

ORCID: https://orcid.org/0000-0001-5095-9461

Can Türksever, Ege University, Engineering Faculty, Food Engineering Department, 35030, Bornova, Izmir, Turkey,

E-mail: canturksever@gmail.com

ORCID: https://orcid.org/0000-0001-9627-023X

Pınar Akın, Ege University, Engineering Faculty, Food Engineering Department, 35030, Bornova, Izmir, Turkey,

E-mail: pinarakin96@gmail.com

ORCID: https://orcid.org/0000-0002-5434-4306

Aylin Acar, Ege University, Engineering Faculty, Food Engineering Department, 35030, Bornova, Izmir, Turkey,

E-mail: aylinacar94@gmail.com

ORCID: https://orcid.org/0000-0002-2893-3975

Nil Deniz Adman, Bak Packaging Company AOSB 10002

Street no. 45, 35620, Cigli, Izmir, Turkey,

E-mail: nildeniz.adman@,bakambalaj.com.tr

ORCID: https://orcid.org/0000-0003-2905-4291

Corresponding author: * 